\title{
Prognostic role of Ape/Ref-1 subcellular expression in stage I-III breast carcinomas
}

\author{
FABIO PUGLISI', FABIO BARBONE ${ }^{2}$, GIANLUCA TELL ${ }^{5}$, GIUSEPPE APRILE ${ }^{1}$, BARBARA PERTOLDI, \\ CONCETTA RAITI ${ }^{3}$, MARK R. KELLEY ${ }^{6}$, GIUSEPPE DAMANTE ${ }^{4}$, ALBERTO SOBRERO ${ }^{1}$, \\ CARLO ALBERTO BELTRAMI ${ }^{3}$ and CARLA DI LORETO ${ }^{3}$
}

\begin{abstract}
${ }^{1}$ Chair of Clinical Oncology, ${ }^{2} \mathrm{Chair}$ of Hygiene, ${ }^{3} \mathrm{Chair}$ of Anatomic Pathology and ${ }^{4} \mathrm{Chair}$ of Genetics, University of Udine, Udine, Italy; ${ }^{5}$ Department of Biochemistry, Biophysics and Macromolecular Chemistry University of Trieste, Italy; ${ }^{6}$ Herman B Wells Center for Pediatric Research, Department of Pediatrics, Indiana University School of Medicine, Indianapolis, IN, USA
\end{abstract}

Received September 20,2001; Accepted October 24, 2001

\begin{abstract}
The purpose of the study was to evaluate the prognostic role of the DNA repair protein APE/Ref-1 in breast carcinomas. Immunohistochemical analysis for APE/Ref- 1 was performed in a series of 133 consecutive stage I-III breast carcinomas. The relationship between APERef- 1 and other prognostic and predictive factors such as tumor size, nodal status, histologic grade, p53 expression, hormonal receptor status, vascular invasion and necrosis was investigated. The prognostic value of APE/Ref-1 was studied by univariate and multivariate analysis. The predominant pattern of APE/Ref-1 immunohistochemical expression was nuclear, although cytoplasmic and mixed nuclear/cytoplasmic localization was also observed. The percentage of cells with APE/Ref- 1 cytoplasmic stain directly correlated with the percentage of $\mathrm{p} 53$ positive cases (rho $=0.28, \mathrm{p}=0.013$ ). The small group of women whose tumors showed mixed nuclear/ cytoplasmic APE/Ref- 1 localization $(n=5$ ) experienced a significantly poorer survival $(p=0.014)$ and Cox proportional hazard model analysis identified APERef- $\perp$ as an independent prognostic factor. The results suggest that subcellular localisation of APE/Ref-1 may influence the aggressiveness of breast carcinomas.
\end{abstract}

Correspondence to: Dr Fabio Puglisi, Clinica Oncologica, Policlinico Universitario, Piazzale S.M. Misericordia 1-33100 Udine, Italy

E-mail: fabio.puglisi@med.uniud.il

Abbreviations: AP, apurinic/apyrimidinic or baseless; APE, AP endonuclease; Ref-1, redox effector factor 1; BER, base excision repair; $A B C$, avidin-biotin-peroxidase complex; $E R$, estrogen receptor; $\mathrm{PR}$, progesterone receptor; $\mathrm{PBS}$, phosphate buffered saline: $O S$, overall survival; $H R$, hazard ratio

Key words: DNA repair, breast carcinoma, immunohistochemistry, prognosis, multivariate analysis

\section{Introduction}

Genomic stability is achieved by avoiding errors during DNA duplication and tepairing damage that spontaneously may occur. Base loss from human cellular genome has been estimated to nearly $10^{4}$ per cell per day under physiological conditions, representing the most important spontaneous mammalian DNA damage (1-5). Moreover, this high rate of depurination can be increased by a variety of factors, such as ionizing madiations or cytotoxic agents. To counteract this intrinsic threat to genome integrity, cells express endonucleases, which specifically recognize AP (apurinic/ apyrimidinic) sites of base loss (6).

The human AP endonuclease 1 (APE/Ref-1) protein belongs to a homologous family of DNA repair proteins, which are highly conserved from bacteria (e.g., E. coli) to insects, plants and rodents (7-9). Structure and function studies of the $37 \mathrm{kDa}$ APE/Ref- 1 protein have described at least three different activities pertaining to distinct protein domains which function independently $(10,11)$ : i) APE/Ref-1 rapidly initiates a DNA repair process by introducing DNA strand breaks on the 5 side of baseless sites. The deoxyribose phosphate residue is subsequently removed by a phosphodiesterase, followed by abolishing the nucleotide gap by DNA polymerase and DNA ligase, which seals the nick, thus restoring the correct DNA seguence (12). ii) APE/Ref-1 may aiso regulate the DNA-binding activity of several transcription factors involved in cell proliferation and differentiation (cFos, c-Jun, c-Myb, Pax proteins) (13-15). The N-terminal domain and the Cys65 residue of APE/Ref- 1 are necessary for this function, while the same residue is not required for endonuclease activity (16). iij) Moreover, recent data indicate APE/Ref- 1 as the first non-covalent modifier of $p 53$ function in cells. In fact, APE/Ref- 1 plays a crucial role in the activation of $p 53$, both in redox-dependent and independent ways (17).

Since APE/Ref-1 is a main actor in the maintenance of DNA integrity and in the control of cell proliferation, its expression has been studied in a variety of tumors, including lung (18), colon (19) and breast cancer (20). In this latter tumor, APE/Ref- 1 can be detected both in the nucleus and in the cytoplasm and nuclear expression was inversely associated 
With lymph node status and angiogenesis, although survival did not correlate with APE/Ref-1 status (20).

In the present work, we exanined the prognostic value of APE/Ref-1 in a series of 133 conseculive breast carcinomas. We also studied the relntionship between APE/Ref-1 and other well-known prognostic and predictive factors, including lumor size, nodal status, histologic grade, p53 expression, estrogen receptorstatus (ER), vascular invasion and necrosis.

\section{Patients and methods}

Breast cancer specimen were obtained from 133 female patients diagnosed at the University and the General Hospitals of Udine, Italy, between 1992 and 1997 . The median patient age at diagnosis was 60.5 years (range $33-88,25 \mathrm{th}-75 \mathrm{ch}$ percentiles $51-70$ ). All primary cancer patients had no distant melastases. Sections of the resected tumors were examined for the histological type (according to the guidelines of the World Health Organization), histological grade (according to Elsion and Ellis crileria), the presence or absence of vascular invasion and the presence or absence of necrosis. Tumors were histologic variants of invasive breast carcinomas, comprising 120 ductal, 6 lobular, 1 tubular and 6 other lypes. In all cases, tumor size was measured in the fresh state and confirmed by re-assessment in the microscopic sections. Median tumor size was $1.7 \mathrm{~cm}$ (range $0.2-7.5,25 \mathrm{~h}-75 \mathrm{th}$ percentiles 1.2-2.4). Lymph node metastases were present in $41.35 \%$ of patients. Histological grade was evaluable in 126 cases, comprising $37.3 \% \mathrm{G} 1,34.9 \% \mathrm{G} 2$ and $27.8 \% \mathrm{G} 3$.

The pathologic stage (pStage) was $I$ in 58 patients, It in 58 and 111 in 17 patients. Other tumor characteristics are shown in Table I.

Complete follow-up information was available on 133 patients, with a median follow-up duration of 66.03 months (1ange 10.6-98.70). At the lime of analysis, $106(79.7 \%$ ) pationls were alive.

Various regimes of adjuvant therapy were administered to the patients and information about treatment was not available for all cases. For these reasons adjustment for endocrine therapy and/or chemotherapy was intentionally avoided.

Intmunohistochemistry. The immunohistochemical study was performed on fomalin fixed, paralfin-embedded sections of resected specimens by the avidin-biotin-peroxidase complex (ABC Elite Vectastain, Veclor, Butlingame, CA, USA) using specific antibodies Ip53(D07) YLEM, Avezzano, Italy; ER(IDS) Dako, Glastup, Denmark]. The sections were freshly cut immediately before immunostaining.

After blocking of endogenous peroxidase with hydrogen peroxide, the sections for ER and p53 were pretreated in a $750 \mathrm{~W}$ microwave oven set at maximum power for $2 \mathrm{~min}$ and at $200 \mathrm{~W}$ for 6 min with $0.01 \mathrm{M}$ cimate buffer, pH 7.3 ; then sections were cooled and washed twice in phosphate buffered siline (PBS). Following overnight incubation with primary antibodies diluted in PBS (DO7 1:100; 1D5 1:400), the avidinbiolin-peroxidase complex was applied for $30 \mathrm{~min}$ at room temperature. Diaminobenzidine tetrahydrochloride (Sigma, St. Louis, MO, USA) was used as chromogen, and hematoxylin was used as counterstaining. Appropriate positive and negative controls were included. For negative controls, the primary antiserum was omitted and replaced with mouse immunoglobulin (Dako).

The percentage of nuclei positive for ER and p53 was scored. Approximately 1000 tumor cells were counted for each case.

For statistical purposes a cut-off point of $\geq 10 \%$ of immunoreactive cells was chosen to define tumors positive for $E R$ and $\mathrm{p} 53$.

Immunohislochemistry for APE/Ref-1. For each case, a minimum of four serial seclions of representative formalinfixed paraffin embedded blocks of breast cancer tisstes were cut onto silane-conted slides and dewaxed. After blocking of endogenous peroxidase, sections were subjected to two microwave irradialions for $5 \mathrm{~min}$ at $800 \mathrm{~W}$ and for $10 \mathrm{~min}$ at $200 \mathrm{~W}$ in $10 \mathrm{mM}$ citrate buffer, pH 6.0 for antigen retrieval. The sections were incubated with rabbit antiserum to APE/Ref-1 diluted 1:50 in PBS overnight at $4^{\circ} \mathrm{C}$. After washing, the biotinylated goat anti-rabbit antibody at a dilution of $1: 200$ and the avidin-peroxidase detection system (ABC Elite Vectastain Vector Laboratories, Burlingame, CA, USA) were applied bolh for $30 \mathrm{~min}$ at room temperature. Peroxidase activity was detected with 3,3'-diaminobenzidine tetrachloride (Sigma) and a light hamatoxylin counterstain was applied. Negative controls were carried out replacing the primary antiserum with pre-immune rabbit serum. The specificity of antiserum to APE/Ref-1 was previously described (21).

A brown staining in the nucleus and/or in the cytoplasm indicated the cellular presence of APE/Ref-1 (Fig. 1). The APE/Ref-I expression was evaluated calculating separately nuclear and cytoplasmic reactivity in 1000 neoplastic cells and was expressed as a percentage of positive cells.

Immunoreactivity for APE/Rel-1 was independently scored by two observers and reported as percentage of neoplastic cells with evidence of "nuclear" and/or "cytoplasmic" stain. Therefore, with respect to subcellular foculization of immunostaining, each tumor was classified as nuclear, cytoplasmic or nuclear/cytoplasmic. The cul-off points to separate varios categories were optimised at $\geq 56$ and $15.95 \%$ for nuclear and cytoplasmic localization respectively, on the basis of the median value of the immunorenctive cases. The different groups were defined as follows: i) the "nuclear' group with $\geq 56 \%$ of cells with APE/Ref-1 immunoreactive nuclei and $<15.95 \%$ of cells with cytoplasmic expression; ii) the "cyloplasmic" group, with $\geq 15.95 \%$ of cells APE/Ref-1 positive in the cytoplasm and $<56 \%$ of cells with Ref-1 nuclear reaclivity; iii) the 'nuclear/cytoplasmic' group, with both $\geq 56 \%$ of cells showing APE/Ref-1 positive nuclei and $\geq 15.95 \%$ of cells showing a Rel-1 cytoplasmic reaction; iv) the "negative" group in which the percentage of cells with nuclear and cytoplasmic APE/Ref- 1 expression was below the defined cutoff points.

No different scotes for intensity of inmunostaining were adopled because of the negligible differences observed among the positive cases.

Sialistical analysis. The Mann-Whitney or the KruskalWallis analyses were performed, as appropriated, to test the hypothesis of a difference in APE/Ref-1 expression among 


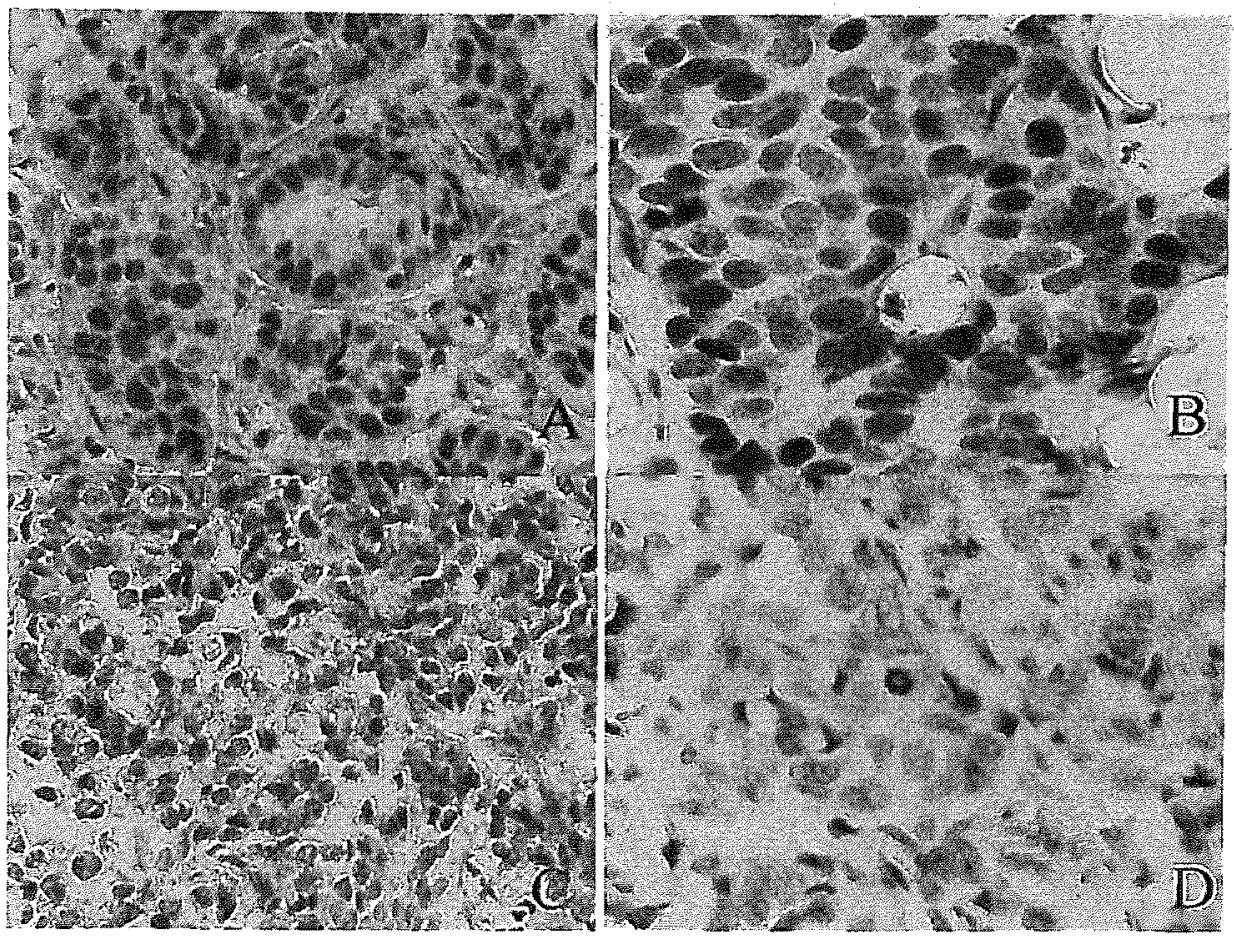

Figure 1. Duchal breast carcinonas showing nuclear (A), mixed nuclear/cytoplasmic (B), cytoplasmic (C) and negative (D) immunohistochemucal staining for APERef-1.

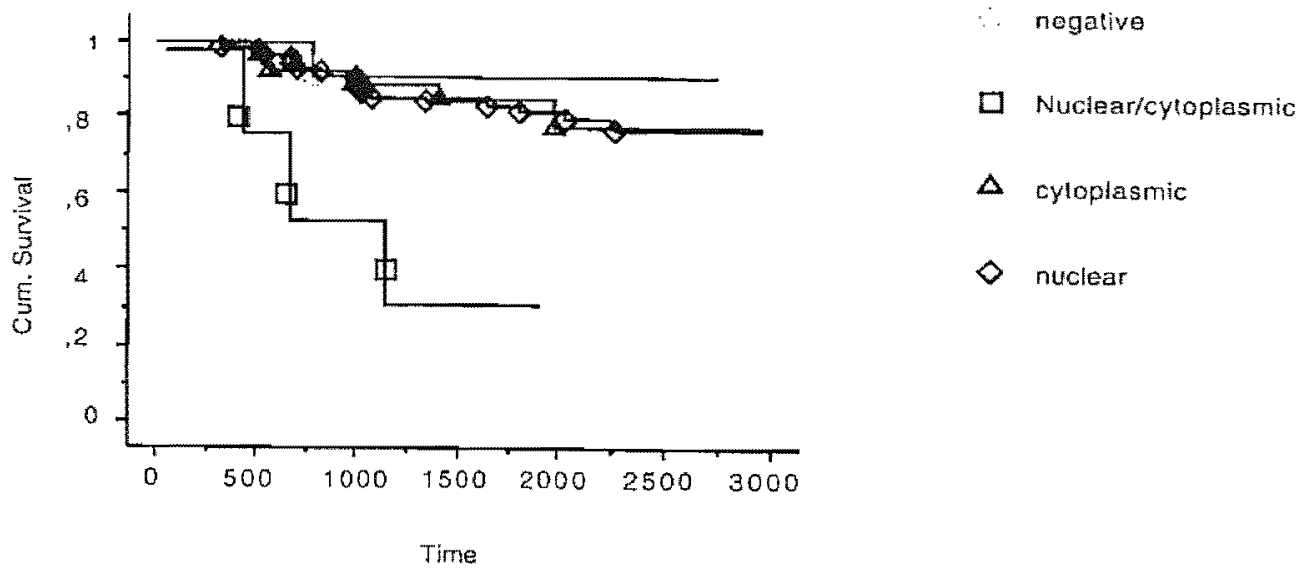

Figure 2. Kaphn-Meier survival curves are shown for tumors with different localization of APE/Ref-1 immunostaining (log-rank test, $p=0.01$ ).

the two or three groups of each tumor characteristics. Association between categorical variables was evaluated by means of $x^{2}$ analysis. To evaluate the correlation between continuous variables Spearman's test was used.

Survival data of the patients were obtained from the Laboratory Information System of the Institute of Anatomic Pathology. Overall survival (OS) was calculated as the time from the date of surgery to the date of denth or last follow-up. Postoperative survival curves were constructed using the KaplanMeier method and then compared using the log-rank test.

The inlluence of APE/Ref-1 expression, adjusted for other covariates, was assessed in a multivariate analysis by the $C o x$ proportional hazards model. Cox models were performed on stepwise (backward) procedures that always forced APE/Ref-1 into the model along with any variables which satisfied an entry level of $\mathrm{p}<0.05$ and, as the model added terms, did not exceed an exit level of $p>0.05$.

\section{Results}

The predominant pattern of APE/Ref-1 expression observed in this series of breast carcinomas was nuclear. In particular, the median percentage of cells wilh nuclear stain was $46.9 \%$ (25th-75th percentiles, 19.7-72.75) among all cases and $56 \%$ (25th-75th percentiles, 26.07-74.87) among nuclear immunoreactive cases. The median percentages of cells with cylo- 
Table I. Mortality among 133 women with breast cancer by clinical and pathology characteristics.

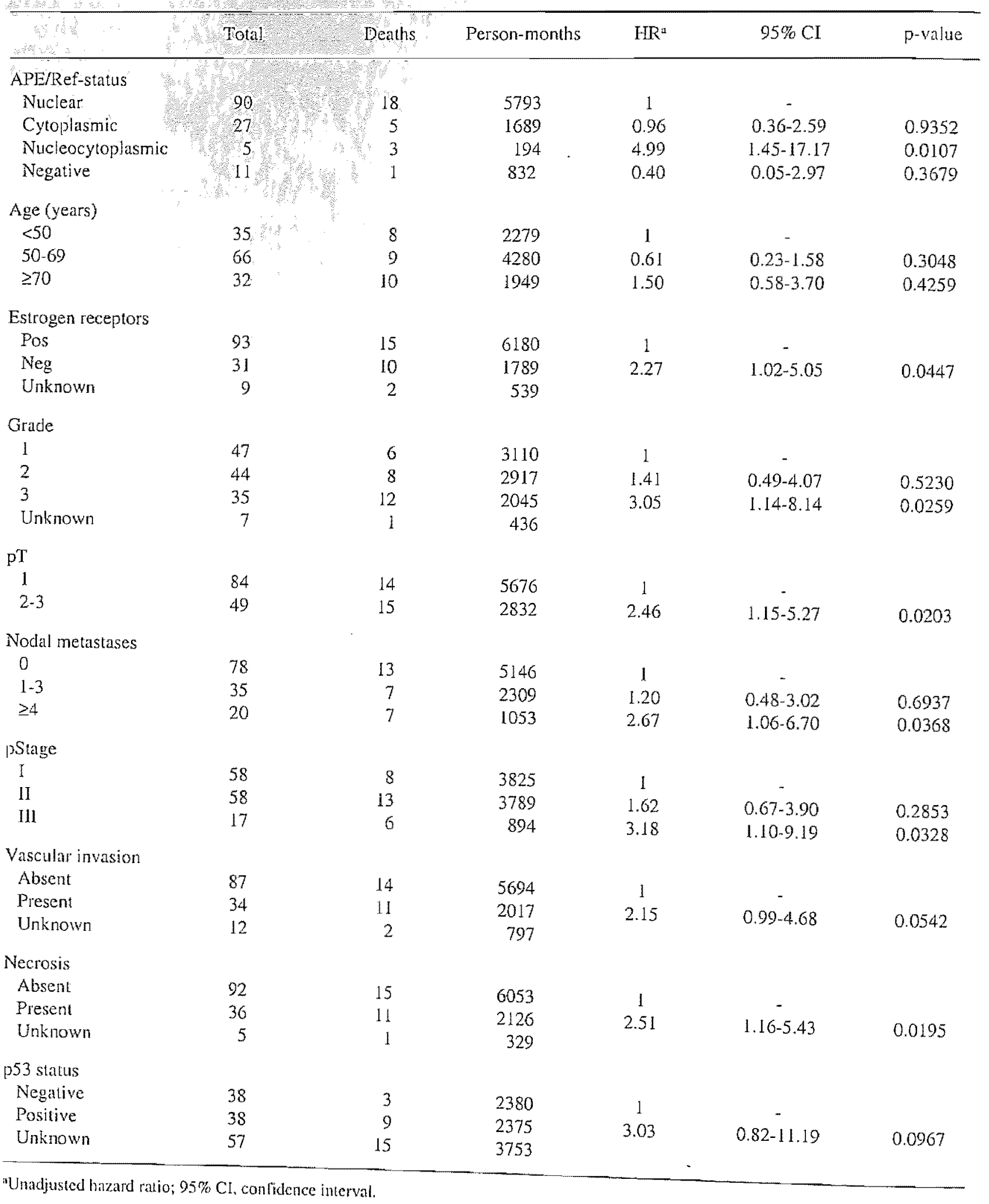

Unadjusted hazard ralio; $95 \% \mathrm{Cl}$, conlidence interval.

plasmic reactivity was $1.6 \%$ (25th-75th percentiles, $0-20.8$ ) among all cases and $15.95 \%$ (25th-75th percentiles, $3.10-45.5)$ among cases with cytoplasmic positivity only.
No significant difference in APERef-1 nuclear expression was observed depending on the pStage $(p=0.96)$, nodal status $(p=0.57)$, tumor size $(p=0.52)$, histologic grade $(p=0.14)$, 
Table II. Multivariate analysis of APE/Ref-l pattern, histologic grade, number of metastatic lymph nodes, and tumor size among 133 women with breast cancer:

\begin{tabular}{|c|c|c|c|c|c|c|c|}
\hline & $\begin{array}{l}\mathrm{HR}^{*} \\
95 \% \mathrm{Cl} \\
\mathrm{p} \text {-value }\end{array}$ & $\begin{array}{l}\mathrm{HR}^{\mathrm{b}} \\
95 \% \mathrm{CI} \\
\mathrm{p} \text {-value }\end{array}$ & $\begin{array}{c}\mathrm{HR}^{*} \\
95 \% \mathrm{CI} \\
\text { p-value }\end{array}$ & $\begin{array}{c}\mathrm{HR}^{\mathrm{d}} \\
95 \% \mathrm{CI} \\
\text { p-value }\end{array}$ & $\begin{array}{c}\mathrm{HR}^{*} \\
95 \% \mathrm{Cl} \\
\mathrm{p} \text {-value }\end{array}$ & $\begin{array}{c}\mathrm{HR}^{\mathrm{r}} \\
95 \% \mathrm{CI} \\
\mathrm{p} \text {-value }\end{array}$ & $\begin{array}{c}\text { HRE } \\
95 \% \text { CI } \\
p^{-v a l u e ~}\end{array}$ \\
\hline \multicolumn{8}{|l|}{ APE/Ref-1 } \\
\hline Nuclear-cytoplasmic & $\begin{array}{c}4.77 \\
1.34-17.00 \\
0.0161\end{array}$ & $\begin{array}{c}4.47 \\
1.28-15.59 \\
0.0189\end{array}$ & $\begin{array}{c}5.22 \\
1.54-17.69 \\
0.0080\end{array}$ & $\begin{array}{c}5.13 \\
1.46-17.96 \\
0.0106\end{array}$ & $\begin{array}{c}5.22 \\
1.55-17.59 \\
0.0076\end{array}$ & $\begin{array}{c}4.64 \\
1.36-15.81 \\
0.0060\end{array}$ & $\begin{array}{c}5.89 \\
1.74-19.89 \\
0.0043\end{array}$ \\
\hline $\begin{array}{l}\text { Histologic grade } \\
3\end{array}$ & $\begin{array}{c}1.87 \\
0.81-4.33 \\
0.1425\end{array}$ & $\begin{array}{c}2.19 \\
0.97-4.94 \\
0.0585\end{array}$ & $\begin{array}{c}1.96 \\
0.87-4.43 \\
0.1044\end{array}$ & & $\begin{array}{c}2.53 \\
1.18-5.40 \\
0.0170\end{array}$ & & \\
\hline $\begin{array}{l}\text { No. of lymph node metastases } \\
\geq 4\end{array}$ & $\begin{array}{c}1.29 \\
0.47-3.55 \\
0.6165\end{array}$ & $\begin{array}{c}1.69 \\
0.66-4.36 \\
0.2780\end{array}$ & & $\begin{array}{c}1.54 \\
0.58-4.05 \\
0.3864\end{array}$ & & $\begin{array}{c}2.30 \\
0.96-5.49 \\
0.0620\end{array}$ & \\
\hline $\begin{array}{l}\mathrm{pT} \\
>1\end{array}$ & $\begin{array}{c}1.93 \\
0.82-4.56 \\
0.1339\end{array}$ & & $\begin{array}{c}2.06 \\
0.92-4.65 \\
0.0800\end{array}$ & $\begin{array}{c}2.24 \\
0.97-5.15 \\
0.0579\end{array}$ & & & $\begin{array}{c}2.57 \\
1.20-5.50 \\
0.0155\end{array}$ \\
\hline
\end{tabular}

"From a proportional hazard model that simultancously included ref, grade, number of in meta and T; "From a proportional hazard model that simultaneously included APE/Ref-1 status, histologic grade and number of lymph node metastases; "From a proportional hazard model that simultaneously included APE/Ref- 1 status, histologic grade and $\mathrm{p} T$; "From a proportional hazard model that simultaneously included APE/Ref-1 status, number of lymph note melastases and $p T$; "From a proportional hazard model that simultaneously included APE/Ref-I status and histologic grade; From a proportional hazard model that simultaneously included APE/Ref-I status and number of" lymph node metastases;

necrosis $(p=0.36)$, vascular invasion $(p=0.86)$, oestrogen receptor status $(p=0.44)$ and $p 53$ status $(p=0.83)$.

There appeared to be no differences in level of cytoplasmic APE/Ref-1 expression according to the pStage $(p=0.49)$, nodal status $(p=0.67)$, tumor size $(p=0.19)$, histologic grade $(p=0.77)$, necrosis $(p=0.18)$, vascular invasion $(p=0.94)$ and oestrogen receptor status $(p=0.11)$. Percentage of cells with APE/Ref-1 cytoplasmic stain directly correlated with percentage of p53 positive cells $(\mathrm{p}=0.28, \mathrm{p}=0.013)$.

Table I summarises the unadjusted hazard ratios (HR) describing the risk of death associated with tumor characteristics. The univariate analysis showed that tumor size, histologic grade, nodal status, hormonal receptor status, APE/Ref-I expression and necrosis all had prognostic value. A marginal effect on survival was also noted for vascular invasion and p53 status. Kaplan Meier survival curves for tumors with different patterns of APE/Ref-1 expression are shown in Fig. 2. Although APE/Ref-1 nuclear/cytoplasmic immunostaining was observed only in five cases, all the women whose tumors showed mixed localisation experienced a significantly poorer survival rate (log-rank test, $\mathrm{p}=0.014$ ).

When APE/Ref- 1 expression was included in the Cox multivariate analysis, it relained significance as an independent prognostic factor in the models tested (Table II).

\section{Discussion}

Base losses [apurinic/apyrimidinic (AP) sites] from human DNA represent the most important spontaneous DNA damage in cells $(2,4-6)$. The rate at which these lesions occur is high per se and can be increased by the insult of DNA damaing agents such as drugs or radiation (20). In the absence of cellular defence mechanisms to repair and prevent a high rate of these DNA damages, cell death and/or mutagenesis are inevitable. All cells have developed various strategies to maintain the integrity of genome.

APE/Ref-1, also known as Hap-1/APEX is an enzyme that plays a key role in the process of base excision repair (BER). It belongs to the family of the so-called AP endonucleases whose main function is to initiate a repart cascade culminating in replacement of the AP site with the correct bases $(6,10)$. Besides the activity in DNA repair, APE/Ref-1 is involved in the redox regulation of transcription factors by stimulating the DNA binding activity of various proto-oncogene products such as c-Jun, c-Fos, c-Myb and Pax proteins (13-15).

Derangement of DNA repair mechanisms is well recognized as a pathogenetic event in cancer progression (23).

Accordingly, there is accumulating interest about the biologic role of APE/Ref- 1 in tumors. In particular it has 
been hypothesised that different subcellular localisation of the protein could correspond to specific functions related to the process of DNA repair. Therefore, alterations in normal activity of APE/Ref-1 have been suggested as possible determinants of abnormal phenotypes.

A prognostic role of APE/Ref- 1 was described by Kakolyris er al in a consecutive series of early operable nonsmall cell lung carcinomas (18). The authors reported a survival benefit for patient whose tumors expressed nuclear APE/Ref-l over the defined cut-off value. No significant difference in survival was noted according to cytoplasmic, mixed nuclear and cyloplasmic, or negative APE/Ref-I expression. Interestingly, the best survival advantage was seen when tumors expressed nuclear APE/Ref-I positivity together with p53 negativity (likely expression of a wild-type p53).

Other studies addressing the prognostic value of APE/Ref-1 found interesting associations between APE/Ref-I pattern and tumoral characteristics. Recently, different expression of APERef-I between ovarian adenocarcinomas of low malignant potential and other ovarian carcinomas has been reported (24). A cytoplasmic immunostaining was predominantly encountered in ovarian carcinomas whereas only two carcinomas of low malignant potential presented some areas with this pattern. On the basis of these observations the authors speculate that, in ovarian cancers, the presence of a strong cytoplasmic staining could represent a marker of malignant behaviour. Qualitative (subcellular localization) rather than quantitative differences in APE/Ref-I expression were also reported during the various steps of the sequence normal colonic mucosat-adenomn-carcinoma (19).

The pattern of APE/Ref-1 immunostaining and its progrostic obe in breast cancer has been previously investigated (20). No relationship belween APE/Ref-I status and survival was observed although APE/Ref-I nuclear localisation was associated with negative nodal status and with low angiogenesis.

In the present study we have demonstrated a survival disadvantage for patients whose tumors showed APE/Ref-1 stain in both nuclear and cytoplasmic compartments $(H R=4.99$, conlidence limits $=1.45-17.17, p$-value $=0.01$ ). In addition, on multivaltiate analysis, the prognostic significance of APE/Ref-1 was retained independently from the other main predictors of survival such as histological grade, nodal status and tumor size (Table II). However, our results merit to be interpreted with caulion because of the paucity of cases presenting the combination of nucleus and cyloplasmic APERef-1 expression (only $4 \%$ of the study population). The biological significance depends entirely on whether or not this small group of 5 patients represents a discrete entily. Nevertheless, the validity of our findings is strengthened by the observation that consistent results are obtaned after small perturbation of the cut-off points (data not shown).

No adequate information on adjuvant treatment of patients was available in our retrospective unselected series. So, no conclusions can be drawn about a potential role of APERef-1 expression as prediclor of response to therapy. This hypothesis is however very tempting on the basis of pre-clinical data indicating the APE/Ref-1 activity in mechanisms of repair after the insult of DNA dimaging agents.
The discordance between the present report and the work by Kakolyris et al regarding the prognostic role of APE/Ref-1 in breast cancer could be explained on the basis the different method of APE/Ref-1 evaluation, respectively mixed qualitative/quantitative and qualitative alone. In fact, the same authors found a relationship between APE/Ref-I pattern and survival in their lung cancer series when they considered the percentage of APE/Ref- 1 stained cells according to its localization inside the cell (18).

The implications for the poor survival rate (more aggressiveness) observed for women in which breast tumors shawed nuclearicytoplasmic localization instead of those showing only cytoplasmic localization of APE/Ref-1, are difficult to understand. In a very recent report, Kelley et al suggested that a cytoplasmic localization of APE/Ref-1 in prostate cancers could be due to its reverse movement from the nucleus to cytoplasm (25). Another possibility could be envisaged and is related to the fact that, due to its relatively high molecular weight, APE/Ref-1 requests an active mechanism for its localization into the nucleus, such as importins (26), and a subsequently inducible mechanism of regulation (i.e., phosphorylation, de-phosphorylation) as is the case of the NF-AT transcription factor (27). In this view, the altered subcelfular localization of APE/Ref- 1 could be an epiphenomenon of the alteration of the mechanism of nuclear shutting, due to the neoplastic phenotype of the cells. Moreover, it should be kept in mind that several lines of evidence suggest that the APE/Ref-1 protein is highly heterogeneous in the cell, having possible phosphorylating-dependent redox and repair activities. Of note is the recent observation that another post-translational checkpoint for APE/Ref- 1 activity is represented by the redox control of its activity (unpublished dati). Therefore, the only presence of APE/Ref-1 in a cellular compartment is not sufficient, per se, to carry out the potential activity as a repair or redox enzyme. The actual form in which the APE/Ref-1 protein exists (e.g., reduced, oxidized, reduced and phosphorylated, oxidized and phosphorylated, reduced in the redox domain and oxidized in the repair domain, etc.) determined in these previous studies is unknown. The determination of the status of APE/Ref- $I$ in these cancers may provide clues regarding the role it is playing in their initiation, progression and aggressiveness.

\section{Acknowledgments}

The authors wish to tank Mrs. Maura Pandolfi for her significant technical help. Supported in part by grants of CNR (target project on biotechnology) and Regione Friuli Venezia Giulia to GD.

\section{References}

1. Lindhal T: Instability and decay of the primary structure of DNA. Nature 362: 709-715, 1993 .

2. Lindhal T: Repair of Intrinsic DNA mutations. Mutat Res 238: 305-311, 1090.

3. Loeb LA and Preston BD: Mulagenesis by apurinic/apyrimidinic sites. Ann Rev Genel 20: 201-230, 1086.

4. Mol $\mathrm{CD}$. Hosfield $\mathrm{DJ}$ and Tainer $\mathrm{J} A$ : Abasic site recognition by two apurinic/ipyrimidinic endonuclease families in DNA base cxcision repair: the $3^{\prime}$ ends justify the meams. Mutat Res 460 :
$211-220,2000$. 
5. Wilson DM, Takeshita $M$ and Demple $B$ : Abasic site binding by the human apurinic endonuclease, Ape, and determination of the DNA contact siles. Nucleic Acids Res 25; 933-939, 1997.

6. Barzilay $G$ and Hickson ID: Structure and function of apurinic/ apyrimidinic endonucleases. Bioessay 17: 713-719, 1995.

7. Robson $\mathrm{CN}$ and Hickson ID: Isolation of cDNA clones encoding a human apurinic/apyrimidinic endonuclease that corrects DNA repair and mutagenesis defects in $E$. coli xih (exonuclease 111 ) mutants. Nuclejc Acids Res 19: 5519-5523, 1991.

8. Sander M, Lowenhaupt K and Rich A: Drosophila Rprl protein: an apurinic endonuclease with homologous recombination aclivity. Proc Natl Acad Sci USA 88: 6780-6784, 1991.

9. Babiychuk $E$, Kushnir $S$, wan Montagu $M$ and Inze $D$ : The Arabidopsis thaliana apurinic endonuclease Arp reduces human transcription factors Fos and Jun. Proc Nall Acad Sci USA 91: 3299-3303, 1994.

10. Rothwell DG, Barzilay G, Gorman M, Morera S, Freemont P and Hickson ID: The structure and functions of the HAPI/Ref-1 protein. Oncol Res 8: 275-280, 1997.

11. Xanthoudakis S, Miao CG and Curran T: The redox and DNArepair activities of Ref-l are encoded by non-overlapping domains. Proc Natl Acad Sci USA 91: 23.27, 1994

12. Craig $N$, Jolnson $S$, Komachi $K$ and Lindhal $T$ : DNA repair. In: Molecular Biology of the Cell. Alberts B, Bray D, Lewis J, Raff M, Roberts $K$ and Watson D (eds). Garland, New York, pp242-25I, 1994.

13. Xanthoudakis $S$, Miao CG, Wang F, Pan YCE and Curran T: Redox aclivation of Fos-Jun DNA binding activity is mediated by a DNA repair enzyme. EMBO J 11: 3323-3335, 1992.

14. Xanthoudakis $S$ and Curan T: Identification and characterization of Ref-1, a nuclear protein that facilitates AP-1 DNA-binding activity. EMBO J $11: 653-665,1992$.

15. Tcll G, Scaloni A, Pellizzari L, Formisano $S$, Pucillo $C$ and Damante G: Redox polential controls the structure and DNA binding activity of the pared domain. J Biol Chem 273: 25062-25072, 1998.

16. Walker LJ, Robson CN, Black E, Gillespie D and Hickson ID: Identification of residues in the human DNA repair enzyme HAP-I (ref-1) that are essential for redox regulation of Jun DNA binding. Mol Cell Biol 13: 5370-5376, 1993.
17. Jayaraman L. Murthy KGK, Zhu C, Curran T, Xantoudakis S and Prives $C$ : Identification of a redox/repair protein Ref- 1 as a potent activator of 553 . Genes Dev 11: 558-570, 1997 .

18. Kakolyris S, Giatromanolaki A, Koukourakis M, Kaklamanis L, Kanavaros P. Hickson, ID, et al: Nuclear localization of human AP endonuclease 1 (HAPL/Ref-1) associated with prognosis in carly operable non-small cell lung cancer (NSCLC). J Pathol 89: $351-357,1999$.

19. Kakolyris S. Kaklamanis L, Engels K, Turley H, Hickson ID, Galter KC, et al: Human AP endonuclease I (HAP D) expression in a colorectal adcnoma-carcinoma sequence. Cancer Res 57: 1794-1797, 1997.

20. Kakolyris $S$, Kaklamanis L, Engels $K$, et al: Human AP endonuclease 1 (HAP I) protein expression in breast cancer correlates with Jympls nodes status and angiogenesis. $\mathrm{Br} J$ Cancer 77: 1169-1173, 1998 .

21. Xu Y, Moore DH, Broshears J, Liu L, Wilson TM and Kelley MR: The apurinic/apyrimidinic endonuclease (APE/ref-1) DNA repair enzyme is elevaled in premalignantand malignant cervical cancer. Cancer Res 17:3713-3719,1997.

22. Walker LJ, Craig RB, Harris AL and Hickson ID: A role for the human DNA repair enzyme HAPI in cellular protection against DNA damaging agents and hypoxic stress. Nucleic Acids Res 22: $4884-4889,1994$.

23. Locb KR and Loeb RA: Significance of multiple mutations in cancer. Carcinogenesis 21:379-385, 2000.

24. Moore DH, Michael H, Tritl R, Parson SH and Kelley MR: Alterations in the expression of the DNA repair/redox enzyme $\mathrm{APE} / \mathrm{ref}-1$ in the epithelial ovarian cancers. Clin Cancer Res 6 : $602-609,2000$.

25. Kelley $M R$, Cheng $L$, Foster $R$, Tritt $R$, Broshears $J$ and Koch $M$ : Elevated and altered expression of the mullifunctional DNA base excision repair and redox enzyme $A$ pe/ref- 1 in prostate cancer. Clin Cancer Res 7: 824-830, 2001.

26. Kaffman $A$ and O'Shea $E$ : Regulation of nuclear localization: a key to a door. Anmu Rev Cell Dev Biol 15:291-339, 1999.

27. Shibasaki F, Price ER, Milan D and McKeon F: Role of kinases and the phosphalase calcineurin in the nuclear shutting of transcription factor NF-AT4. Nature 382: 370-373, 1996. 